Ekonomia - Wroclaw Economic Review 22/3 (2016)

Acta Universitatis Wratislaviensis

No 3732

DOI: 10.19195/2084-4093.22.3.3

Radosław Wojtyszyn

Prokuratura Okręgowa we Wrocławiu

Współpracownik Instytutu Ludwiga von Misesa

radoslaw.wojtyszyn@mises.pl

\title{
U źródeł leseferyzmu i subiektywizmu myśli Murraya Rothbarda. Arystoteles, Święty Tomasz, hiszpańscy scholastycy, John Locke i Fryderyk Bastiat jako źródła inspiracji
}

\author{
JEL Classification: B11, B12, P14, P16
}

Keywords: St. Thomas, Spanish scholastics, John Locke, Frederic Bastiat, exchange, subjectivism, credit, money, property rights

\begin{abstract}
Laissez - faire and subjective underpinnigs of Murray Rothbard's thought. Aristotle, St. Thomas, Spanish scholastics, John Locke and Frederic Bastiat as an inspiration

The subject of this article are origins of the subjectivist view of the economic activity of man, and pre-classic themes of political economy, which are the inspirations for Murray Newton Rothbard and his thought of anarcho-capitalism. These issues, being so rarely subject to scientific interest, are crucial point of reference for classical and neoclassical economics, and laissez-faire in general. Specific influence of natural law on the sphere of economic activity and human condition also implies a broader view of the role of state institutions in the thought of Aristotle, Thomas Aquinas, the scholastics of the Salamanca, John Locke and Frederic Bastiat, who combined the above-mentioned laws of nature and tradition of classical economics with subjectivity, so important in Austrian School of Economics and in anarcho-capitalist thought of Murray Newton Rothbard.
\end{abstract}

Przedmiotem niniejszego artykułu jest zwięzłe przedstawienie początków subiektywistycznego spojrzenia na ekonomiczne działania człowieka, a także pierwsze, pre-klasyczne wątki ekonomii politycznej (a więc nauki służącej poznaniu i opisywaniu rzeczywistości oraz wskazującej środki do osiągania celów, a także stosowne metody posługiwania się tymi środkami), będące inspiracją i punktem wyjścia dla oryginalnego ujęcia anarchokapitalistycznego autorstwa Murraya Newtona 
Rothbarda. Zagadnienia te, chociaż tak rzadko bywają obiektem zainteresowań naukowych, są ze wszechmiar warte uwagi, stanowią bowiem punkt odniesienia dla ekonomii klasycznej i neoklasycznej oraz ogólnie pojętego leseferyzmu. Swoiste przenikanie prawa natury w sferę ekonomicznego działania człowieka warunkowało również szersze spojrzenie na rolę instytucji państwowych w myśli Arystotelesa, Tomasza z Akwinu, scholastyków z Salamanki oraz Fryderyka Bastiata, łączącego wyżej wspomnianą tradycję prawa natury i klasycznej ekonomii z subiektywizmem charakteryzującym późniejszą tzw. Austriacką Szkołę Ekonomii ${ }^{1}$. Jedną z pierwszych prób ekonomicznego racjonalizowania świata można dostrzec u Arystotelesa. Jego podział kategorii wartości dobra był znamienny dla myśli społeczno-ekonomicznej późniejszych wieków. Stwierdził on bowiem, iż rzecz posiada wartość użytkową i wymienną. Wartość wymienna jest sztuczna, bo bezużyteczna $\mathrm{w}$ rodzinie i pojawia się dopiero z chwilą jej rozdziału. Ludzie nabywają dobra w dwojaki sposób - przez naturalne objęcie ich we władanie lub poprzez handel. Sposób pierwszy służył zaspokojeniu naturalnych potrzeb ludzkich, zaś handel jedynie potrzebie przyjemności, bowiem pojawia się on w wyniku nadmiaru dóbr. $Z$ tego też powodu Arystoteles nisko cenił handel i ludzi nim się trudniących, potępiał pożyczki na procent i lichwę. Niemniej, sformułował kilka ważnych warunków, bez których do wymiany miało nie dochodzić. Przede wszystkim musiała ona przynosić proporcjonalne korzyści obu stronom transakcji. Stąd wywnioskował, że dobra będące przedmiotem wymiany muszą przedstawiać taką samą wartość dla obu stron. Pieniądze sprzyjają zamanifestowaniu ludzkich potrzeb, która to manifestacja określona została przez niego popytem na dane dobro, a więc subiektywnym poczuciem użyteczności danego dobra. Rzadkość dóbr zwiększała, jego zdaniem, ich subiektywną użyteczność, bowiem zbyt duża podaż odbijała się na spadku ich wartości wyrażonej w cenie pieniężnej. To, co istotne, to fakt, iż środki prowadzące do określonego celu (można je nazwać środkami produkcji) uzależniały, według Arystotelesa, swą wartość od wartości celu, jakiemu miały służyć. Co więcej, zauważył on również prawidłowość, w świetle której wartość dobra uzależniona jest od wielkości straty, do jakiej doprowadzi jego utrata (można sformułować tu dwie zależności: 1) A jest więcej warte od B, jeśli jego

1 Przez subiektywizm ekonomiczny rozumiem tu założenie, w świetle którego źródło wartości dóbr upatruje się w sądach działającego człowieka, zaś struktura cenowa na rynku podyktowana jest wypadkową subiektywnych opinii poszczególnych jednostek.

Sformułowanie leseferyzm (fr. laissez faire - pozwólcie czynić; laissez passer — pozwólcie przechodzić, laissez aller) stosowany jest tu przeze mnie w tradycyjnym ujęciu, a więc jako pogląd filozoficzno-ekonomiczny głoszący wolność jednostki, zwłaszcza w wymiarze społeczno-ekonomicznym, głoszący, że realizacja własnych celów jednostek umożliwia wzrost gospodarczy społeczeństwa jako całości.

W końcu sformułowanie „prawo natury” odnosi się do zespołu obiektywnych norm moralnych, wynikających z natury człowieka i poznawalnych rozumowo. To także reguły zachowania lub oceny, wyrastające z ,istoty” lub „natury” zjawiska i zgodnie z którymi powinno się kształtować instytucje ekonomiczne, społeczno-polityczne i prawne. 
dodanie do pożądanego zbioru $\mathrm{C}$ zwiększa jego wartość bardziej niż analogiczne dodanie B; 2) A jest więcej warte od B, jeśli jego utrata przynosi większą szkodę niż utrata $\mathrm{B}$ ). Arystoteles także jako pierwszy dobitnie podkreślił wyższą wartość komplementarnych środków produkcji lub dóbr będących zamiennikami innych (Rothbard, 2006, s. 15-18).

Do zagadnienia wartości wymiennej i sprawiedliwej ceny odniósł się również Tomasz z Akwinu. Wymiana ma co do zasady przynieść korzyść obydwu jej stronom, toteż dla żadnej z nich nie może być ona ciężarem. A zatem musi zachodzić pewna równość pomiędzy dobrami ofiarowanymi przez sprzedawcę i ceną płaconą przez kupującego. Jak stwierdza, cena jest miarą wartości rzeczy potrzebnych do życia. Jeżeli cena przekracza wartość rzeczy lub wartość przekracza cenę, dochodzi do naruszenia sprawiedliwości (Tomasz z Akwinu b.d., II-II, 77, 1-3; Gilson, 1998, s. 368-369). Ale zaraz potem Akwinata czyni zastrzeżenie, iż normalna wartość przedmiotu nie jest jednoznaczna z jego wartością rzeczywistą, jaką przedstawia ona dla sprzedawcy lub kupującego. Dochodzi on do wniosku, iż wartość wymienną określa subiektywne poczucie użyteczności danego dobra, rodzące się w umyśle każdego człowieka. Poziom tej użyteczności znajdował wyraz w popycie na określony produkt lub usługę. Wartość wytworzonego dobra zależała również od ilości pracy włożonej w jego produkcję lub dostarczenie i poniesione w tym zakresie koszty przez producenta lub handlarza. Sprawiedliwą ceną wyrażoną w jednostkach pieniężnych jest cena powstała na wolnym rynku i determinowana przez podaż i popyt na dane dobro w określonym miejscu. Znamienne jest tu przyzwolenie Tomasza na spekulację, a więc racjonalne nabywanie dóbr po niższej cenie i ich sprzedaż po wyższej w miejscach o wysokim na nie popycie. Często wspominany jest w literaturze podany przez niego kazus handlarza zbożem. Akwinata stwierdził, że nie popełnia on grzechu, jeśli sprzedaje zboże po wyższej cenie w miejscu, w którym panuje głód, mimo iż posiada wiedzę o zbliżających się innych karawanach z żywnością i o wywołanym tym faktem spadku cen zboża. Tomasz zauważa, iż kupiec ów nie posiada obowiązku informowania o tym swych nabywców, bowiem dotarcie innych handlarzy jest zdarzeniem przyszłym, a przez to niepewnym (Rothbard, 2006, s. 51-54). Z tego względu jego postępowanie nie obraża sprawiedliwości. Słusznej ceny nie da się ściśle odmierzyć - jest to sprawa oceny i drobne odchylenia nie naruszają sprawiedliwości transakcji. Moralność żąda jedynie, aby sprzedawcy przyświecał zawsze zamiar trzymania się możliwie najbardziej słusznej ceny i aby potrafił go skutecznie zrealizować (Gilson, 1998, s. 370).

Pojawia się tu również kwestia sprawiedliwości sprzedaży z zyskiem. Tomasz uważał wymianę za istotny element integrujący wspólnotę, bowiem za jej pośrednictwem każda ze stron zaspokajała swoje potrzeby. $Z$ tego też względu podkreślał ważną rolę kupców ponoszących ryzyko i trud pracy związany z dystrybuowaniem dóbr z miejsc o ich nadwyżce na tereny o ich deficycie (Rothbard, 2006, s. 53). Spoglądał na handel jako sprawę zasadniczo prywatną i służącą indywidualnym celom. Chęci zarobku może przyświecać szlachetna pobudka, jak utrzymanie 
domu, wykształcenie rodziny lub udzielenie pomocy potrzebującym. Prawo do zysku uzależnione było dostarczaniem usług zaspokajających społeczne potrzeby. Toteż Tomasz potępia jedynie postępowanie polegające na osiąganiu zysku dla niego samego (Tomasz z Akwinu b.d., II-II, 77, 4; Gilson 1998, s. 370-372).

Zawiłymi są rozważania Akwinaty na temat lichwy, a więc oprocentowanych pożyczek. Zasadniczo procentem nazywał cenę płaconą za użytkowanie jakiegoś dobra. Pobieranie procentów od pożyczonych pieniędzy uważał za niedozwolone i niesprawiedliwe, gdyż sprowadzało się ono do sprzedaży czegoś, co nie istnieje (Tomasz z Akwinu 1999a, s. 440-441). Istnieją rzeczy, których użytkowanie pociąga za sobą ich zniszczenie, jak wino lub chleb. W takich wypadkach nie można oddzielić użytkowania rzeczy od niej samej. Gdyby ktokolwiek próbował osobno zbyć wino i prawo do jego wypicia, sprzedawałby dwukrotnie to samo lub coś, co nie istnieje, a zatem dopuściłby się niesprawiedliwości. Również pieniądz jest rzeczą, której użycie doprowadza do jego zniszczenia — powstał, by umożliwić wymianę. Toteż niesprawiedliwym jest żądanie oprócz zwrotu pożyczonej kwoty także odszkodowania za możność używania pieniędzy, gdyż równa się to żądaniu dwukrotnie tej samej sumy. Odnosiło się to zwłaszcza do kredytodawców, których środki pieniężne bezczynnie spoczywały w skrzyniach - argument jakoby procent był ceną za utratę potencjalnego zysku jest bezzasadny, gdyż stanowi to sprzedawanie czegoś, czego się nie posiada i być może nigdy nie będzie posiadało (Tomasz z Akwinu b.d., II-II, 78, 1-2; Gilson, 1998, s. 372-373). Niemniej, Tomasz nie potępiał instytucji pożyczek per se — pozytywnie wypowiadał się o niepieniężnych pożyczkach na procent bądź oddawaniu pieniędzy w zastaw, które nie było równoznaczne z ich wydawaniem (Rothbard, 2006, s. 54-55).

Jednym z najważniejszych uprawnień naturalnych przysługujących istocie ludzkiej, na które zwracali uwagę Arystoteles i św. Tomasz z Akwinu, jest własność, a więc posiadanie i dysponowanie dobrami materialnymi. To właśnie ona znajdowała się w centrum zainteresowania i późniejszych rozważań Murraya Rothbarda.

Arystoteles uważał własność za niezwykle ważną dla człowieka. W przeciwieństwie do Platona opowiadał się on wyłącznie za własnością prywatną, krytykując jej model kolektywny. Po pierwsze uważał, iż wpisana jest ona w naturę człowieka, toteż jej niszczenie uderza $w$ istotę człowieczeństwa. Po drugie, własność prywatna sprzyja kształtowaniu cnoty filantropii, hojności i dzielenia się z innymi. Po trzecie, w przeciwieństwie do własności kolektywnej, sprzecznej z różnorodnością ludzkich istnień, jest ona produktywna i nie prowadzi do konfliktów społecznych (polegających na czerpaniu ze wspólnej własności maksymalnych zysków przy jednoczesnym uchylaniu się od ponoszenia na nią jakichkolwiek nakładów) (Rothbard, 2006, s. 13-15) $)^{2}$. Arystoteles zachęcał do akumulowania własności, a także wyróżnił jej

${ }^{2}$ Można powiedzieć, że tym samym Arystoteles antycypował tzw. tragedię wspólnego pastwiska opisaną przez Garretta Hardina w artykule pt. Science z 1968 r. (Hardin, 1968). Do problemu tego odnosi się m.in. Elinor Ostrom w How Inexorable Is the „,Tragedy of the Commons”? Institutional Arrangements for Changing the Structure of Social Dilemmas (Ostrom, 2016).

Ekonomia - Wroclaw Economic Review 22/3 (2016)

(C) for this edition by CNS 
trzy tytuły, z których prawo i rolnictwo uchodziły za sprawiedliwe, grabież zaś za tytuł godny potępienia (Arystoteles, 2001, s. 121 i n., Dubel, 2005, s. 67).

Ciekawą koncepcję własności przedstawił Akwinata. Stwierdził on, iż człowiek obdarzony wolą i rozumem z natury jest zdolny do posługiwania się rzeczami, a ponieważ nie utrzymałby się przy życiu, gdyby się tymi rzeczami nie posługiwał, to ma do tego naturalne prawo. Własność definiował Tomasz jako moc robienia użytku z jakiejś rzeczy stosownie do swoich potrzeb. Tym samym prawo własności jest prawem naturalnym, opatrzonym rygorem nienaruszalności. Nie należy jednak zapominać o tym, iż kreatorem wszelkiego stworzenia i jedynym jego właścicielem jest Bóg. Jednakże powierzył on człowiekowi stworzonemu na swe podobieństwo prawo wykorzystywania i realnego władania rzeczami w świecie doczesnym. Akwinata zastrzegł, iż na mocy prawa naturalnego użytkowanie dóbr przysługuje wszystkim, stąd też stworzył on dla własności swoiste granice, zaznaczając, iż słuszne jest, by każdy posiadał na własność to, co mu jest potrzebne na własny użytek. Wywnioskować zatem możemy, iż posiadanie na własność tego, czego się nie potrzebuje, jest zagarnięciem dla siebie rzeczy zasadniczo wspólnych, których użytkowanie powinno być wspólne. Nie potępiając bogactwa per se, ale podporządkowując je wymogom rozumnego postępowania, Tomasz stwierdził, iż człowiek bogaty, który nie rozdaje innym posiadanych w nadmiarze i nieprzydatnych dóbr, pozbawia potrzebujących tych rzeczy, które prawnie im przysługują, a więc ograbia ich przemocą. Nie oznacza to jednak, iż prawo naturalne domaga się wspólnoty dóbr ani też, co za tym idzie, że własność indywidualna jest sprzeczna z prawem naturalnym. Wręcz przeciwnie, kluczowa dla osiągnięcia dobra wspólnego jest własność prywatna. Zdaniem Akwinaty ludzie lepiej troszczą się o własny majątek, stąd też własność prywatna sprzyja osiągnięciu pokojowej współpracy i ładu społecznego. Ponadto, motywuje ona do działania i generuje dobrobyt. Twierdził, iż własność daje człowiekowi zadowolenie, a wówczas łatwiej godzi się on ze swym losem. Ponadto, wspólne posiadanie dóbr materialnych stanowi źródło wszelkich niesnasek (Tomasz z Akwinu, b.d. II-II, 66, 1-2; Gilson, 1998, s. 359-360). Tomasz określił także sposoby nabycia własności przez człowieka: pierwszym z nich jest praca jego własnych rąk, jako że istota ludzka posiada prawo własności do samej siebie; drugim zaś jest pierwotne zawłaszczenie dóbr nieznajdujących się we władaniu kogokolwiek (Rothbard, 2006, s. 56-57).

Wspomnieć również trzeba o katalogu przewinień względem prawa własności, jaki sprecyzował Akwinata. Zaliczył do niego kradzież — podstępne przywłaszczenie sobie cudzej własności - i rabunek polegający na wymuszeniu własności przemocą. Tego typu przestępstwa uderzają w ludzką społeczność, a także w miłość Boga i bliźniego. Na bazie przedstawionych wyżej zastrzeżeń za kradzież nie uznaje Tomasz przywłaszczenia sobie w razie potrzeby tego, co człowiekowi niezbędne. A zatem, w razie nagłej i oczywistej konieczności — chodzi tu przede wszystkim o nakarmienie głodnych i odzienie nagich — człowiek 
potrzebujący może przywłaszczyć sobie cudze dobra (zwłaszcza, jeśli należą do ludzi opływających w bogactwo) podstępem lub przemocą, nie dopuszczając się winy (Tomasz z Akwinu, b.d. II-II, 66, 6-7; Gilson, 1998, s. 361).

Kolejne elementy leseferystycznego myślenia odnaleźć można w wieku XVI, który był dla Europy przełomowym na wielu polach życia społeczno-gospodarczego. To okres zmian zarówno w sferze światopoglądowej, jak i materialnego dobrobytu. Odnosząca w tym czasie sukcesy reformacja skłoniła Kościół Katolicki do walki z herezjami, przede wszystkim na polu filozofii. Znaczącą rolę odegrał tu powrót do scholastyki w jej tomistycznym wydaniu. Początkowo wiódł w niej prym zakon Dominikanów, potem zaś jej głównymi przedstawicielami zostali Jezuici. W początkach XVI wieku Hiszpania była jednym z najpotężniejszych i najaktywniejszych krajów Europy, zwłaszcza w odniesieniu do filozofii chrześcijańskiej. Tam też, w 1540 r., założone zostało przez św. Ignacego Loyolę Towarzystwo Jezusowe, znane powszechnie pod nazwą zakonu Jezuitów. Początkowo stawiało sobie ono jedynie praktyczne cele $\mathrm{w}$ walce $\mathrm{z}$ reformacją, mimo iż hiszpańskie duchowieństwo przede wszystkim aktywnie działało na uniwersytetach. Z czasem praca w kolegiach zmusiła Jezuitów do zajęcia się teorią — oparli się oni na tradycyjnej scholastyce tomistycznej, by w efekcie ją unowocześnić i wzmocnić (Tatarkiewicz, 2004, s. 31-32).

Nie bez znaczenia pozostawało przeniesienie punktu ciężkości ówczesnego światowego handlu z basenu Morza Śródziemnego i włoskich miast do Hiszpanii i Portugalii. W wyniku odkryć geograficznych, a także decyzji politycznych władców Francji opodatkowujących szlaki handlowe wiodące z państw włoskich do północnej Europy, a zwłaszcza do flamandzkiej Brugii, państwa Półwyspu Iberyjskiego urosły do rangi potęg handlowych. W parze z ową handlową ekspansją szła inflacja wywołana głównie importem ogromnej ilości kruszców szlachetnych (złoto i srebro) z Nowego Świata na teren Hiszpanii. Narastające z tego powodu problemy stały się również punktem zainteresowania światłych Jezuitów (Rothbard, 2006, s. 99).

Podkreślić należy dokonania na polu ekonomii politycznej, określającej również granice działalności państwa, tzw. szkoły z Salamanki. Mianem tym określa się środowisko jezuitów i dominikanów, skupiające się od lat 30. XVI wieku wokół uniwersytetów w Salamance i Coimbrze - prawników, moralistów, teologów i ekonomistów. Należą do niej m.in. Francisco de Vitoria (1493-1546), Domingo de Soto (1494-1560), Martin de Azpilcueta (1493-1586), Diego de Covarrubias y Leiva (1512-1577), Tomás de Mercado (1530-1576), Luis de Molina (15351600) Juan de Mariana (1534-1622), Francisco de Suárez (1548-1617). Do grupy tej można zaliczyć także prekursora scholastyków z Salamanki — kard. Kajetana (Tomasso de Vio, 1469-1534) oraz niepochodzącego z Hiszpanii Flamanda Leonarda Lessiusa (1554-1623) (Szlachta, 2010, s. 86, przyp. 2).

To właśnie scholastycy z Salamanki utorowali drogę dla współczesnej subiektywistycznej teorii wartości opracowanej przez austriacką szkołę ekonomicz- 
ną, z której wywodzą się m.in. Ludwig von Mises, Friedrich August von Hayek i Murray Rothbard. Podobieństwa między scholastykami a Austriakami zachodzą również na polu teorii sprawiedliwej ceny, pieniądza i bankowości. Ten intelektualny wpływ Salamanki na Szkołę Austriacką nie jest przypadkowy, lecz stanowi konsekwencję bliskich historycznych, politycznych i ekonomicznych związków pomiędzy Hiszpanią i Austrią za czasów Karola V i jego brata Ferdynanda I. Wspomniane więzi trwały kilka stuleci, a przetrwały dzięki Włochom odgrywającym rolę kulturowego, gospodarczego i finansowego łącznika między Hiszpanią a Wiedniem (de Soto, 2009, s. 62, przyp. 77; Teluk, 2009, s. 54-58; Rothbard, 1976, s. 52-74; de Soto, 1996, s. 59-81; Kwaśnicki, 1998, s. 2-8; Chaufen, 2007)33.

${ }^{3}$ Warto również wspomnieć, iż hiszpańscy scholastycy sporo swej uwagi poświęcili idei państwa oraz genezy władzy świeckiej. Wyszli z założenia, iż wszyscy ludzie są z natury wolni i równi. Żadna jednostka nie jest więc z natury zwierzchnikiem innej ze względu na dziedziczny tytuł lub stosunek z Bogiem, większą mądrość lub cnotliwość, albo też przez fakt bycia głową rodziny. Idea naturalnej wolności i równości wsparta jest na koncepcji wolnej woli i roli sumienia w podejmowaniu działań człowieka, jakiej hołdowali uczeni z Salamanki. Natura człowieka jednakże skłania jednostki do życia we wspólnocie, a tym samym dąży do powołania koniecznego władztwa lub zwierzchnictwa powstających spontanicznie wspólnot. Niemniej jednak, powtarzając za Vitorią i Moliną, scholastycy nie przyjęli formy przekazania władztwa w formie umowy społecznej. Nie można mówić, iż byli oni zwolennikami podejścia, w świetle którego jednostki godziłyby się na podporządkowanie, rezygnowały ze swej wolności i wyzbywały wiążących się z nią uprawnień w pełni lub części na rzecz władcy, któremu miałyby podlegać. Działo się tak, ponieważ nie posiadały one, w mniemaniu scholastyków, takich uprawnień, z których mógłby korzystać piastun władztwa - a więc możność stanowienia norm, rozkazywania, decydowania o wojnie i pokoju, sądzenia i stosowania przymusu. Stąd też wyróżnili dwa rodzaje władztwa jakościowo od siebie różne: 1) możność stosowania przymusu przez równe i wolne jednostki na podstawie prawa naturalnego, lecz bez kompetencji do stanowienia norm wiążących innych i zabijania występnych, jedynie pod postacią obrony przed agresją; 2) możność stosowania przymusu przez wspólnotę lub działającego w niej piastuna władztwa, włącznie z kompetencją karania przestępców, stanowienia norm i rozkazywania. Czynnikiem sprawczym istnienia władzy publicznej jest sam Bóg, jednakże jej materialną przyczynę umiejscowili oni we wspólnocie, która z mocy prawa naturalnego wzięła na siebie zadanie rządzenia i administrowania sobą w celu osiągnięcia dobra wspólnego. To właśnie wspólnota nie tyle przekazuje pochodzącą od Boga i prawa naturalnego władzę królowi lub przedstawicielom w zgromadzeniu, co wyposaża ich jedynie w swój autorytet i moc realizacji dobra wspólnego. Warto dobitnie podkreślić, iż wspólnota nie stanowi źródła władzy państwowej, lecz jest jej podmiotem wskazującym panującego lub przedstawicieli mających być instrumentem władzy danej ostatecznie przez Boga i prawo naturalne (Szlachta, 2010, s. 92-105).

Niezwykle rewolucyjne, jak na owe czasy, poglądy na genezę władzy świeckiej prezentował Juan de Mariana. Swoje spostrzeżenia oparł na tezie, iż wspólnota ma prawo odebrać władzę panującemu, który jej nadużywa. Ludzie opuścili stan natury na rzecz porządku państwowego w celu ochrony swej nietykalności cielesnej i własności prywatnej. W trakcie procesu przechodzenia do stanu państwowego i przenoszenia uprawnień na władcę, część z nich jednostki zachowały wyłącznie dla siebie - 1) prawo do wypowiedzenia posłuszeństwa; 2) prawo do opodatkowania; 3) prawo do elekcji władcy w przypadku, gdy dotychczasowy panujący nie posiada następcy. Mariana sprecyzował również pojęcie tyrana, względem którego wspólnota może stawić opór — tyranem jest władca uciskający poddanych ze względu na ich wiarę, narzucający podatki bez ich zgody i uniemożliwiający zebranie się ciała przedstawicielskiego, jeśli takie istniało. W powyższych wypadkach

Ekonomia - Wroclaw Economic Review 22/3 (2016)

(C) for this edition by CNS 
Scholastycy z Salamanki posiadali dokładnie sprecyzowaną teorię państwa, podyktowaną sposobem zapatrywania się na ekonomię. Zasadniczą funkcją władzy jest obrona obywateli i zarządzanie sprawiedliwością. Niewątpliwie ochronie takiej miała służyć instytucja konfiskaty mienia jako kara za popełnione przestępstwo. Scholastycy, zauważając skłonność władzy do stałego rozszerzania swych kompetencji, ulegania pokusie nieograniczonego bogacenia i zaspokajania wygórowanych potrzeb, opowiadali się za jej minimalizowaniem. Wszelka aktywność państwa musiała być wsparta sprawiedliwymi podatkami, a więc świadczeniami fiskalnymi uznawanymi przez wspólnotę, popartymi określonymi potrzebami w wymiarze wymaganym nie tylko do funkcjonowania państwa, ale zaakceptowanym przez poddanych. Tym samym byli oni zwolennikami ograniczonej polityki fiskalnej i przeciwnikami deficytu w skarbie państwowym. Krytykowali grupy społeczne żyjące z przymusowych poborów, wykazując że wygórowane podatki zmuszają chłopów do emigracji. Argumentowali, iż rozbudowana administracja sprzyja rozwojowi łapownictwa, złodziejstwa i korupcji, a urzędnikom łatwiej przychodzi wydawanie publicznych pieniędzy. Na równi z oszustwem traktowali instytucję monopoli państwowych, które poprzez udzielenie przywileju dostarczania określonego dobra tylko jednemu sprzedawcy uderzały $\mathrm{w}$ dobrowolne transakcje (Teluk, 2009, 58-61; Chaufen, 2002, s. 69, 128-131).

Odnosząc się do kwestii gospodarczych, scholastycy podkreślali, iż z praktycznego i moralnego punktu widzenia wolny rynek jest zawsze lepszy od etatyzmu. Diego de Covarrubias y Leiva za czynniki wpływające na wartość danego dobra na rynku uznał jego użyteczność i rzadkość. Owa wartość nie była uwarunkowana wewnętrznymi cechami rzeczy lub jej produkcji, ale subiektywnymi ocenami konsumentów. Sprawiedliwa cena zaś zależeć miała nie tylko od kosztów wyprodukowania i nakładów pracy, ale także od wartości rynkowej dobra. Covarrubiasowi wtórował Luís Saravia de la Calle Veronese, uznając cenę jako interakcję zachodzącą między użytecznością i popytem rynkowym a rzadkością podaży. Luís de Molina jako sprawiedliwą cenę traktował tylko tę powstałą na wolnym rynku, bez oszustw i monopolu, w wyniku powszechnej oceny wartości określonego dobra przez ludzi mieszkających na danym obszarze. Wartość rzeczy upatrywał w ludzkim umyśle, a nie w niej samej. Juan de Mariana zwracał uwagę na nienaruszalność prawa własności. Uważał, iż król może wydawać swą własność, ale nie ma prawa naruszać w całości bądź części własności innych jednostek. Mariana miał negatywny stosunek do procederu bogacenia się w administracji państwowej, a zrównoważony budżet, lecz niekoniecznie oparty na wysokim obciążeniu podatkowym, był dla niego rzeczą najważniejszą. W wysokich podatkach źródło biedy i niedoli widział także Fernandez Navarette. Natomiast na zasadniczą kwestię podaży pieniądza zwrócił uwagę Martin de Azpilcueta, głoszący, iż w krajach cier-

każda jednostka posiadała uprawnienie do pozbawienia tyrana życia, bez uzyskiwania wcześniejszej zgody wspólnoty - Mariana jednakże za stosowniejsze uważał uprzednie przekonanie reszty poddanych do swych racji (Rothbard, 2006, s. 117-120). 
piących na niedobór pieniądza wszelkie dobra, a nawet praca ludzka, są tańsze niż w wypadku, gdy tych pieniędzy byłoby w bród. Inflację zniekształcającą relacje między kredytodawcą a dłużnikiem i zmniejszającą wartość dóbr potępiał Tomás de Mercado. Domingo de Soto (1495-1560) podjął problem płacy pracowników, pisząc, iż nie mogą oni okradać swych pracodawców, tłumacząc się niskimi zarobkami, gdyż owa płaca jest wynikiem wcześniejszej dobrowolnej zgody obu stron. Scholastyk ten głosił także tezę, że prywatna inicjatywa działa lepiej od inicjatywy publicznej, naznaczonej marnotrawstwem bogactwa (Kwaśnicki, 1998, s. 6-7).

Przedstawiciele szkoły z Salamanki podjęli również problematykę lichwy i oprocentowanych pożyczek. W przeważającej większości opowiadali się za pożyczkami w sferze zawodowego obrotu handlowego lub inwestycji przynoszących nawet potencjalny zysk. Co więcej, oprocentowanie, a więc lichwa, była legitymizowana ryzykiem niespłacenia pożyczonej kwoty — ryzyko, a dokładnie fakt wystawienia na nie własności, może stanowić zbywalny za określoną cenę przedmiot transakcji. Brak płynności finansowej wskutek pożyczenia pieniędzy stanowi dla pożyczkodawcy uciążliwą przykrość, stąd też oprocentowanie pożyczki ma ową przykrość i straconą użyteczność wynagrodzić. Ponadto, ludzie wyżej cenią dobra teraźniejsze od dóbr przyszłych, dlatego bardziej pragną posiadać pieniądze w chwili obecnej niż w przyszłości. Oprocentowanie to nic innego jak sprawiedliwa cena użyczenia komuś środków pieniężnych, czyli zrzeczenia się teraźniejszych pieniędzy na rzecz przyszłych. Cena ta winna być ustalana każdorazowo przez strony umowy (Rothbard, 2006, s. 101, 107-109, 124-126).

Wspomnieć również należy, iż teoretycy szkoły salamanckiej dokonali wnikliwej analizy praktyk bankowych i byli poprzednikami różnych stanowisk teoretycznych, które zdominowały myśl ekonomiczną dwa wieki później. Analiza ta pozwala wyróżnić wśród nich dwie grupy — pierwszą, skupioną wokół osób Savarii de la Callego, Martina de Azpilcuety i Tomása de Mercado, a krytycznie odnoszącą się do systemu bankowości opartej na rezerwie cząstkowej; a także drugą, powiązaną głównie z Luisem de Moliną i Domingiem de Soto, opowiadającą się za mało restrykcyjnymi podstawami prawnymi umowy bankowego depozytu pieniężnego i akceptującą działalność opartą na rezerwie cząstkowej. Krytycy rezerwy cząstkowej argumentowali, że odsetek nie da się pogodzić z naturą depozytu bankowego oraz że to bankier powinien otrzymywać wynagrodzenie za ochronę pieniędzy i ich bezpieczne przechowywanie. Bankierzy osiągają nieproporcjonalne zyski wskutek bezprawnej praktyki przywłaszczania sobie depozytów i ich wykorzystywania we własnym interesie pod postacią udzielania oprocentowanych pożyczek. Taka działalność prócz tego, iż stanowi grzech ciężki, doprowadza do ekspansji kredytowej, a w efekcie do późniejszej recesji. Odmienne poglądy przedstawiali Molina i de Soto. Uważali oni praktykę pożyczania zdeponowanych pieniędzy stronom trzecim za uprawnioną dopóty, dopóki bankierzy działali rozważnie. Kryterium rozważnego działania nie zostało jednak przez nich sprecyzowane i uniemożliwiło wyeliminowanie nadużyć oraz pogwałceń zasad prawnych 
w sferze bankowości, skutkujących recesją i upadkami banków. Spojrzenie to było wynikiem błędnego utożsamiania depozytu bankowego z odwołalną pożyczką. Na uwagę zasługuje jednak fakt, iż to Luis de Molina jako pierwszy uświadomił sobie, że czeki oraz inne dokumenty uprawniające do wypłaty na żądanie pewnych kwot z depozytów pełnią dokładnie tę samą rolę co gotówka - toteż to on winien być uznany za ojca teorii, w świetle której depozyty na żądanie w bankach stanowią część ogólnej podaży pieniądza, a tym samym wpływają na gospodarkę w ten sam sposób jak drukowany pieniądz (Huerta de Soto, 2009, s. 61-72, 454-462).

W kwestii pieniądza zbliżone stanowisko do Salamanki prezentował w XVII wieku John Locke. Przede wszystkim stanowczo sprzeciwiał się przymusowemu obniżaniu stopy procentowej odsetek od udzielonych kredytów i pożyczek. Argumentował, iż takie działanie spowoduje redystrybucję oraz ograniczenie oszczędności i kredytów, pogarszając tym samym stan gospodarki. Poziom stopy procentowej powinien być ustalany naturalnie, a więc za pośrednictwem wolnego rynku - poprzez działania wolnych ludzi w ramach prawa natury czyli bazując na podaży i popycie na pożyczki w danym czasie. Locke potępiał również obniżanie wartości monety. Podkreślał, iż prawdziwa wartość pieniądza określana jest ilością zawartego w niej srebra, a nie wartością na niej widniejącą i określaną przez władzę. Kładąc w swoich poglądach nacisk na twardą walutę, ostrzegał, że obniżenie wartości jest iluzoryczne i inflacyjne, rozrzedzając jedynie realną wartość pieniądza, a więc jego siłę nabywczą. Państwowa mennica winna pełnić rolę gwaranta utrzymania jednostki monetarnej jako definicji lub standardowej wagi kruszcu. Jakakolwiek zmiana wartości pieniądza byłaby tak samo arbitralna i oszukańcza, jak zmiana definicji jednostek pomiaru odległości lub czasu. Co więcej, władze, będąc poręczycielem wykonywania warunków każdej umowy, dewaluując pieniądz, zwalniają dłużnika z wykonania warunków umowy, bowiem wierzyciel traci odpowiedni procent ustalonej wartości tego, co mu się należy (Rothbard, 2006, s. 317-323; Rau, 1992, s. 54-55).

Tak jak wspomniani wcześniej Arystoteles i Akwinata, również John Locke uczynił własność prywatną jednym z najistotniejszych uprawnień prawnonaturalnych. Teorię naturalnego prawa do własności oparł na prawie do samoposiadania każdej jednostki. Podstawę do ustanowienia czyjegoś pierwotnego prawa do surowców oraz posiadania ziemi lub innych zasobów stanowiła praca. Własność prywatna wywodzi się ze wspólnego posiadania albo braku własności i przeradza się w osobiste władztwo w ten sam sposób, w jaki człowiek przekształca nieużywane dobro - poprzez połączenie własnej pracy, osobistej energii z nieużywanym i nieposiadanym zasobem. W ten sposób dobro jest produktywnie używane, co konstytuuje wyłączność jego posiadania przez osobę, która jako pierwsza jej użyje. Samoposiadanie każdej jednostki i pierwsze użycie lub pierwotne zawłaszczenie zasobów rodzą naturalność i moralność prawa do własności. Tak powstałe tytuły dają uprawnienie do wymiany posiadanej własności na podstawie dobrowolnych umów, a także do swobodnego jej darowania osobom trzecim (Locke, 1992, 
s. 181-191; Rau, 1992, s. 44-52; Modrzejewska, 2010, s. 27-31). Podkreślić należy, iż koncepcja ta nosi miano laborystycznej teorii własności — określającej, jak dobra prawowicie stają się czyjąś własnością dzięki pracy i wysiłkowi — i nie ma nic wspólnego z laborystyczną teorią wartości wyjaśniającą determinanty wartości lub ceny towarów i usług na rynku (Rothbard, 2006, s. 316-317; Vaughn, 1978).

$\mathrm{Na}$ proces kształtowania się leseferyzmu duży wpływ miał przedstawiciel francuskiej szkoły klasycznej ekonomii, polityk liberalny i niezrównany polemista - Fryderyk Bastiat (1801-1850). Publicystyka jego pióra ukazywała się od 1844 roku w postaci licznych artykułów i pamfletów ekonomicznych, a także esejów, jak Co widać i czego nie widać, Sofizmaty ekonomiczne, Prawo, Kapital i renta, Przeklęty pieniadz, Protekcjonizm i komunizm (Hazlitt, 2006). Charakterystycznym jest sposób prezentacji przez niego poglądów. Oparł go on na tzw. argumentum ad absurdum, czyli sprowadzaniu do absurdu wywodów adwersarzy przy konsekwentnym użyciu ich sposobu argumentacji (chociażby w Petycji producentów świec) (Hazlitt, 2006; Bastiat, 2006; DiLorenzo, 2003, Bastiat, 2005; Thornton, b.d.; Hülsmann, 2001, s. 55-70).

Bastiat najbardziej znany jest ze swych studiów ekonomii politycznej, w których badał zależności między państwem a gospodarką, starał się pojąć istotę państwa i jego działania. Rząd, według niego, winien ograniczyć się do podstawowych funkcji, czyli zapewnienia przestrzegania prawa, bez którego społeczeństwo nie może istnieć, ale równocześnie zauważał, że prawa te winny być godne poszanowania (DiLorezo, 2003). Co niezwykle istotne, rozważania swe podporządkował dwóm kategoriom: prawu naturalnemu i ekonomii.

W eseju pt. Prawo próbował odpowiedzieć na pytania: Czym jest prawo? Czym prawo faktycznie się stało? Jakie prawo być powinno? Co warunkuje sprawiedliwe prawa? Genezą ustawodawstwa jest prawo naturalne, na które składa się życie, wolność i własność. Owe prawo stanowione to, według autora, zbiorowa organizacja indywidualnych uprawnień do ochrony życia, wolności i własności. Organizacja, której wolno czynić tylko to, do czego naturalne uprawnienia mają jednostki, mająca również dbać o prawa wszystkich oraz zapewnić panowanie sprawiedliwości nad wszystkimi. Obecnie prawo faktycznie odwróciło swe ostrze przeciwko tym, których miało chronić — normy prawne, będąc poparte grupową siłą, podjęły się ograniczania wolności i własności, zalegalizowały rabunek pod postacią różnorakich świadczeń na rzecz państwa, a wszelką ochronę przed nim spenalizowały. Legalny rabunek następuje, gdy prawo zabiera jednym to, co do nich należy, wbrew ich woli i bez zadośćuczynienia, dając innym osobom, które nie mają do tego prawa; gdy prawo daje korzyści jednemu obywatelowi kosztem innego w sposób, jakiego sam obywatel nie może się podjąć nie popełniając przestępstwa. Państwo za pomocą aparatu przymusu poczęło organizować ludzkie zajęcia, handel, rolnictwo, przemysł, naukę, sztukę, nadając normom kształt ,praw do", a tym samym zatracając ich właściwy, negatywny charakter, mający opierać się wyłącznie na ochronie jednostek („wolność od”) (Bastiat, 2003, s. 13-35). 
Zasadniczą funkcją prawodawcy winno być zagwarantowanie bezpieczeństwa, a nie kontrola nad osobami i ich mieniem; gwarancja swobodnego wykonywania prawa do wolności sumienia, woli, myśli, wykształcenia, pracy, przyjemności oraz zapobieganie ich pogwałceniu, nie zaś regulacja tych wszystkich dziedzin. Sprawiedliwość to równość wobec prawa - sprawiedliwe prawo nie preferuje nikogo ani nie podporządkowuje kogokolwiek komukolwiek, to warunek zachowania godności ludzkiej i droga do postępu. Moralne uzasadnienie prawa nie może być oparte na głosie większości, ponieważ żadna jednostka nie ma kompetencji, by zniewalać innych, a tym bardziej nie ma jej grupa jednostek. Za czynnik implikujący właściwy kierunek polityki i prawa uznawał Bastiat ekonomię jako naukę określającą, kiedy interesy istot ludzkich są ze sobą zgodne, a kiedy antagonistyczne (Bastiat, 2003, s. 59-65).

Wzajemne relacje między prawem a własnością winny, zdaniem Bastiata, opierać się na prymacie tej drugiej. Własność stanowiła dla niego atrybut przynależny każdej istocie ludzkiej z samego jej faktu bycia człowiekiem. Widać zatem wyraźnie, że wyprowadzał ją z natury ludzkiej. Wszelkie prawa podyktowane są istnieniem własności, tym samym to nie normy prawne ją warunkują i określają. Stanowi ona przedłużenie osoby i jako taka jest koniecznością dla ludzkiej egzystencji — pozbawienie człowieka własności sprowadza się do odebrania mu jego przyrodzonych zdolności i prowadzi do śmierci. Stąd też widział Bastiat własność boską instytucją, która wyznaczać miała treść norm prawnych służących jej ochronie (Bastiat, 1968a; Wyszyński, 2006).

Bastiat krytycznie odnosi się do instytucji państwa, traktując je jak twór, dzięki któremu każdy usiłuje żyć kosztem innych. Sprzeciwia się spoglądaniu na nie jak na oderwany i niezależnie istniejący od społeczeństwa byt. Państwo musi mierzyć się ze sprzecznymi interesami i żądaniami — aby spełnić jedne, zawsze zmuszone jest naruszyć inne. Ich realizacja finansowana jest z przymusowych świadczeń fiskalnych, stąd też Bastiat podkreśla grabieżczą naturę państwa (Bastiat, 2006b, s. 27-33).

Interwencjonizm i jego skutki od strony ekonomicznej przedstawił Francuz w eseju Co widać i czego nie widać. Otwiera go podziałem na dobrych i złych ekonomistów. Ci pierwsi widzą skutki szybkie i widoczne, jakie wywołuje każde działanie w ekonomii, ale także są w stanie przewidzieć te odległe i niewidoczne. Drudzy zwracają uwagę wyłącznie na to, co widać bezpośrednio. Centralnym punktem eseju staje się alegoria zbitej szyby, która w tej czy innej formie będzie się przewijać przez dalszą treść dzieła. Zbicie owej szyby przynosi stratę właścicielowi i pożytek szklarzowi - zdarzenie to przyspiesza bowiem obieg pieniądza i pozornie wspomaga przemysł. $Z$ drugiej strony jednak powyższa szkoda uniemożliwia właścicielowi zbitej szyby alokację środków w innych gałęziach, poprzez zakupienie nowego, dodatkowego dobra. Bastiat uczy więc patrzeć globalnie, zauważać drugą, niewidoczną stronę medalu (Bastiat, 2003a, s. 14-16). Wyraźnie podkreśla, iż każda forma redystrybucji dóbr nie tworzy bogactwa, a tylko je przesuwa, z czym wiążą się określone konsekwencje, uderzające za- 
zwyczaj w konsumentów. Autor odwołuje się do takich problemów jak podatki, roboty publiczne, dotowanie sztuki, protekcjonizm, finansowanie armii, pośrednictwo w handlu, mechanizacja produkcji, upowszechnienie kredytu, oszczędność i konsumpcja, a także prawo do pracy i prawo do zysku (Bastiat, 2003a, s. 16-55).

Wolny handel uważał Bastiat za najlepszą metodę zachowania pokoju i pomyślności obywateli, a cła utożsamiał z powodem wojen. Protekcjonizm był w jego oczach próbą nałożenia na obywateli tych samych sposobów krzywdzenia, jakie stosowali wrogowie podczas działań zbrojnych. Konkurencja wolnorynkowa była dla niego procesem odkrywczym, w którym każda osoba, w celu osiągnięcia zamierzeń ekonomicznych, koordynowała własne plany. Rządowa regulacja naruszała tę procedurę, gdyż prawo zastępowało ludziom ich inteligencję, potrzebę dyskusji, porównań i poszukiwań, odbierało im osobowość, wolność i mienie, a oni sami przestawali być ludźmi (DiLorenzo, 2003; Bastiat, 2006a; Bastiat, 2006c; Lewiński, 2011, s. 9-32; Lewiński, 2007, s. 265-271). Spuściznę intelektualną Francuza podjęła w drugiej połowie XIX wieku Austriacka Szkoła Ekonomii.

Podsumowując, już pierwsze próby ekonomicznego racjonalizowania świata i ludzkiego działania w nim odrzucały obiektywistyczną teorię, zgodnie z którą wartość dobra określają takie obiektywne czynniki, jak ilość włożonej w jego wytworzenie pracy i koszty produkcji. To sądy wartościujące poszczególnych ludzi, wypadkowa ich subiektywnych opinii decydują o strukturze cenowej na danym rynku. Prawidłowość tę postrzegano jako prawo natury warunkujące istnienie wymiany dóbr w ogóle - dochodziło do niej tylko dlatego, że ludzie różnie oceniali ich wartość. Ale to nie wszystko - owo prawo natury, tak silnie zakorzenione w świecie i człowieku, kazało krytycznie spoglądać na wszelkie działania uderzające w zasady wspomnianej wymiany, a także we wszystko, co było jej podstawą lub pochodną, a więc m.in. we własność prywatną, pieniądz, kredyt i wolny handel. Jakakolwiek interwencja wpływająca na ich strukturę lub wartość była wymierzona przeciwko naturze i człowiekowi. Bazując na późniejszych dokonaniach tzw. Austriackiej Szkoły Ekonomii, powyższe zagadnienia z całą mocą rozwinął Murray Newton Rothbad w swojej oryginalnej koncepcji porządku społecznego biorącego za podstawę przyrodzone każdej istocie ludzkiej uprawnienia naturalne i wyrastający z nich niezakłócony leseferyzm gospodarczy, w myśl której społeczeństwo, opierając swój byt na swobodnej wymianie dóbr i usług, może obejść się bez instytucji państwa.

\section{Bibliografia}

Arystoteles (2001), Polityka, [w:] Arystoteles, Dzieła wszystkie, Warszawa. Arystoteles (2001a), Dzieła wszystkie, Warszawa.

Bastiat F. (2003), Co widać i czego nie widać, Lublin-Rzeszów.

Bastiat F. (2006a), Harmonie ekonomiczne, Instytut Ludwiga von Misesa, http://mises.pl/pliki/upload/harmonie.pdf (dostęp: 30.06.2015). 
Bastiat F. (2006b), Państwo, Lublin-Chicago-Warszawa.

Bastiat F. (2006), Petycja producentówświec, http://mises.pl/blog/2005/07/27/206/(dostęp:30.06.2015). Bastiat F. (2003), Prawo, Lublin.

Bastiat F. (1968a), Property and Law, [w:] idem, Selected Essays on Political Economy, Foundation for Economic Education 1968, http://bastiat.org/en/property_law.html (dostęp: 30.06.2015).

Bastiat F. (2006c), Przeklęty pieniądz, Instytut Ludwiga von Misesa, http://mises.pl/pliki/upload/ przeklety.pdf (stan na 30.06.2015).

Bastiat F. (1968), Selected Essays on Political Economy, Foundation for Economic Education 1968, http://bastiat.org/en/property_law.html (dostęp: 30.06.2015).

Bastiat F. (2005), Teoria a praktyka, http://mises.pl/blog/2005/09/24/222/ (dostęp: 30.06.2015).

Chaufen A.A. (2002), Chrześcijanie za wolnością. Ekonomia późnoscholastyczna, Kraków.

Chaufen A.A. (2007), Wiara i wolność. Myśl ekonomiczna późnych scholastyków, Warszawa.

Ciborowski R., Kargol-Wasiluk A., Zalesko M. (red.) (2011), Ekonomiści Szkoły Austriackiej, Białystok.

DiLorenzo T. (2003), Frederic Bastiat (1801-1850): tacznik francuskiej tradycji i marginalistycznej rewolucji, http://mises.pl/blog/2003/12/06/65/ (dostęp: 30.06.2015).

Dolan E.G. (red.) (1976), The Foundations of Modern Austrian Economics, Kansas City (Missouri).

Dubel L. (2005), Historia doktryn politycznych i prawnych do schytku XX wieku, Warszawa 2005.

Gilson E. (1998), Tomizm. Wprowadzenie do filozofii św. Tomasza z Akwinu, Warszawa.

Hardin G. (1968), Science.

Hazlitt H. (2006), Bastiat Wielki, http://mises.pl/blog/2006/02/10/263/ (dostęp: 30.06.2015).

Huerta de Soto J. (1996), New Light on the Prehistory of the Theory of Banking and the School of Salamanca, „Review of Austrian Economics”, vol. 9, no. 2, http://mises.org/journals/rae/pdf/ RAE9_2_4.pdf (dostęp: 30.06.2015).

Huerta de Soto J. (2009), Pieniadz, kredyt bankowy i cykle koniunkturalne, Warszawa.

Hülsmann J.G. (2001), Bastiat's Legacy in Economy, ,Quarterly Journal of Austrian Economics”, vol. 4, no. 4, December 2001, http://mises.org/journals/qjae/pdf/qjae4_4_3.pdf (dostęp: 30.06.2015).

Kwaśnicki W. (1998), Ekonomia klasyczna - spojrzenie z innej perspektywy, „Ekonomista”, nr 5-6, http://kwasnicki.prawo.uni.wroc.pl/todownload/Ekonomia\%20klasyczna.pdf (dostęp: 30.06.2015).

Lewiński J. (2011), Claude Frédéric Bastiat (1801-1850), [w:] Ekonomiści Szkoły Austriackiej, red. R. Ciborowski, A. Kargol-Wasiluk, M. Zalesko, Białystok.

Lewiński J. (2007), Wspótczesne znaczenie teorii wartości Frédérica Bastiata, [w:] Studia Erasmiana Wratislaviensia. Wrocławskie Studia Erazmiańskie I, red. M. Sadowski et al., Wrocław.

Locke J. (1992), Dwa traktaty o rządzie, Warszawa.

Modrzejewska M. (2010), Libertariańskie koncepcje jednostki i państwa we współczesnej amerykańskiej myśli politycznej, Kraków.

Ostrom E. (2016), How Inexorable Is the „Tragedy of the Commons”? Institutional Arrangments for Changing the Structure of Social Dilemmas), http://www.indiana.edu/ koertge/H205/ Commons.htm (dostęp: 12.06.2016).

Rau Z. (1992), Wstęp [w:] J. Locke, Dwa traktaty o rzadzie, Warszawa.

Rau Z., Chmieliński, M. (red.) (2010), Umowa społeczna i jej krytycy w myśli politycznej i prawnej, Warszawa.

Rothbard M.N. (2006), Economic Thought Before Adam Smith: An Austrian Perspective on the History of Economic Thought, vol. I, Ludwig von Mises Institute, Auburn.

Rothbard M.N. (1976), New Light on the Prehistory of the Austrian School, [w:] The Foundations of Modern Austrian Economics, red. E.G. Dolan, Kansas City (Missouri).

Sadowski M., Bojek, E., Machaj, M., Szymaniec, P. (red.) (2007), Studia Erasmiana Wratislaviensia. Wrocławskie Studia Erazmiańskie, I, Wrocław.

Ekonomia - Wroclaw Economic Review 22/3 (2016)

(C) for this edition by CNS 
Szlachta B. (2010), Przedstawiciele katolickiej szkoty z Salamanki wobec umowy spotecznej, [w:] Umowa społeczna i jej krytycy w myśli politycznej i prawnej, red. Z. Rau, M. Chmieliński (2010), Warszawa.

Tatarkiewicz W. (2004), Historia filozofii, T. II, Warszawa.

Teluk T. (2009), Libertarianizm. Krytyka, Gliwice-Warszawa.

Thornton M. (b.d.), Frédéric Bastiat as an Austrian Economist, „Journal des économistets et des études humaines" $11(2 / 3)$.

Tomasz z Akwinu, Św., (1999), Dzieła wybrane, Kęty.

Tomasz z Akwinu, Św., (1999a), O kupnie i sprzedaży na kredyt, [w:] Dzieła wybrane, Św. Tomasz z Akwinu (1999), Kęty.

Tomasz z Akwinu, Św., Suma teologiczna, b.m.w., b.d.

Vaughn K. (1978), John Locke and the Labor Theory of Value, „, The Journal of Libertarian Studies” 2, $\mathrm{nr} 4,1978$.

Wyszyński T. (2006), Własność nie jest przywilejem, [w:] F. Bastiat, Harmonie ekonomiczne, Instytut Ludwiga von Misesa, http://mises.pl/pliki/upload/harmonie.pdf (dostęp: 30.06.2015). 